\title{
FEATURE Sequestering carbon and increasing productivity by conservation agriculture
}

Rattan Lal

$\mathrm{T}$ he quantum jump in food production and progress toward elimination of mass starvation have been driven by mechanization of plowing and other farm operations, introduction of input-responsive varieties, use of chemical fertilizers along with herbicides and pesticides, increase in supplemental irrigation, and reliance on information and communication technology. Notable among the consequences of the agricultural revolution between 1960 and 2015 are increase in (1) human population from 3 billion to 7.3 billion (United Nations 2014); (2) atmospheric concentration of carbon dioxide $\left(\mathrm{CO}_{2}\right)$ from $316 \mathrm{ppm}$ to $400 \mathrm{ppm}$ (IPCC 2014); (3) global temperature by $0.12^{\circ} \mathrm{C}\left(0.22^{\circ} \mathrm{F}\right)$ per decade (IPCC 2014); (4) problems of soil degradation by erosion, salinization, depletion of soil organic matter (SOM), and nutrient imbalance (Bai et al. 2008); (5) depletion, pollution, and eutrophication of natural waters; and (6) risk of extinction of soils (Tenseson 2014) and species. Yet, food production must be increased by another 1 billion $\mathrm{t}$ ( 1.1 billion $\mathrm{tn}$ ) by 2050 , while also restoring the degraded soils and ecosystems, reducing net anthropogenic emissions, and improving the environment.

Plow-based agriculture has exacerbated the problems of accelerated soil erosion by water and wind, oxidation of SOM, and decline in soil structure (aggregation) and tilth. The plow-related problems of environmental degradation were highlighted by the Dust Bowl of 1930s in the United States (Steinbeck 1939) and in China since 2000; soil degradation and desertification in Sub-Saharan Africa (SSA), South Asia, the Caribbean, etc. (Bai et al. 2008); and the excessive withdrawal of water from aquifers such as of the Ogallala (United States), Indo-Gangetic Plains (South Asia), and the Huang-Huai-Hai Plains (China). Thus, there has been a growing interest in developing a plowless agriculture with

Rattan Lal is a distinguished university professor of soil science and director of the Carbon Management and Sequestration Center, The Ohio State University, Columbus, Ohio. possibility of lesser impact on soil and the environment (Lal et al. 2007; Lal 2009).

While some traditional farmers (e.g., in SSA, the Andean region, and the Caribbean) have been sowing crops in undisturbed field by using a digging stick or a hand-held hoe for millennia, sowing crops in an untilled soil on commercial farms originated in the US Corn Belt during late 1950s, primarily in response to the severe problem of soil erosion by water and wind. In the 1940s, discussions on pros and cons of plowless agriculture or no-till (NT) farming started with the publication of two books, Plowman's Folly (Faulkner 1943) and the The Furrow and Us (Jack 1946). In the wake of ruinous Dust Bowl, Faulkner blamed the moldboard plow for disastrous pillage of the soil, and Time Magazine termed the Folley-Jack debate as "the hottest farming argument since the tractor first challenged the horse" (Jack 2007).

Because of the strong impact of tillage or its elimination on soil organic carbon (SOC) pool and its dynamics, objective deliberations on this theme must continue, especially during 2015 International Year of Soil, because of its critical role as a source/sink of atmospheric $\mathrm{CO}_{2}$, methane $\left(\mathrm{CH}_{4}\right)$, and nitrous oxide $\left(\mathrm{N}_{2} \mathrm{O}\right)$; the urgency to feed an ever growing and increasingly affluent world population; the need to minimize risks of water contamination, eutrophication, and nonpoint source pollution from agricultural runoff; and the importance of enhancing biodiversity. The fact that present agriculture is more reliant on input rather than on efficiency increase raises the stakes even higher. Therefore, a holistic and systembased approach to soil management as the engine for increasing productivity by improving efficiency and making agriculture environmentally compatible is more important now than ever before.

As anthropogenic greenhouse gas (GHG) emissions increase due to global economic and population growth and the atmosphere and oceans warm, there is a strong need to identify potential $\mathrm{C}$ sinks of storing atmospheric $\mathrm{CO}_{2}$. The terres- trial C cycle is an important sink of the anthropogenic C emissions (LeQuéré et al. 2014; Running 2008), and soil C pool is a critical component of this sink. While improving productivity and advancing food security, SOC storage in depleted and degraded agricultural lands can also partly offset anthropogenic emissions and improve the environment.

Soils of agroecosytems have lost a large part of the antecedent SOC pool by erosion, decomposition, and leaching. The magnitude of SOC loss from cultivated soils is estimated at $15 \mathrm{Mg} \mathrm{ha}^{-1}\left(13,390 \mathrm{lb} \mathrm{ac}^{-1}\right)$ in China (Song et al. 2005), but may be much higher for soils in SSA and South Asia (Lal 2004). Discussions on the importance of terrestrial $\mathrm{C}$ cycle and its changes since the ice age gained momentum in the 1990s (Crowley 1995). Yet, our knowledge is grossly insufficient (Falkowski et al. 2000), especially to describe the impact of agricultural perturbations (plowing) on the soil C pool and dynamics at local, regional, and global scales. Therefore, critical questions which must be addressed include the following:

1. Does conversion from plow tillage (PT) to conservation agriculture (CA) merely redistribute $\mathrm{SOC}$ in the profile, or can the SOC pool be increased on longterm basis, especially in the subsoil where it is away from the zone of intense natural and anthropogenic perturbations?

2. What land use and soil management systems can create a positive soil $\mathrm{C}$ budget?

3. Is CA a viable option for increasing the SOC pool (Schlesinger 2000; Powlson et al. 2014) and sustaining agronomic yield (Pittelkow et al. 2014) in a changing and uncertain climate?

4. What policy interventions may facilitate adoption of best management practices (BMPs) of land use and soil/ crop management (Hammons 2009)?

5. What makes sense and nonsense in application of CA (Kirkegaard et al. 2014) to achieving long-term sustainability of agroecosystems (Rasmussen et al. 1998; Bockstaller et al. 2008)?

The objective of this article is to answer these questions and explain how to judi- 
ciously and prudently use CA to harness its potential as a conservation-effective technology, climate-resilient agriculture, and a viable option for sustainable intensification of agroecosystems for advancing food and nutritional security, and for adaptation/mitigation of climate change.

\section{DEFINITIONS AND TERMINOLOGY}

The awareness during 1940s regarding the need for the elimination of plowing and retention of crop residue mulch on the surface led to several practices and the associated terminology to describe the new concept of seedbed preparation based on the need for reducing soil disturbance and retaining of crop residue mulch for soil and water conservation (figure 1). During the 1960s and 1970s, a range of terms (NT, zero tillage, direct seeding, conservation tillage, minimum tillage, mulch tillage, and strip tillage) were used. However, indiscriminant use of these terms, often using the same term to describe different practices, has exacerbated confusions and controversies. Therefore, standardization of terminology is important.

\section{CONSERVATION AGRICULTURE: A SYSTEMS APPROACH}

Since the late 1990s, there has been a greater emphasis on a system approach to NT farming, and this is called "conservation agriculture" (CA). Conceptually, CA encompasses four basic principles (figure 2): (1) retaining crop residues as surface mulch, (2) including cover crops in the rotation cycle, (3) improving soil fertility by integrated nutrient management (INM) for healthy crop growth and biochemical transformation of biomass $\mathrm{C}$ into SOM or humus (Lal 2014), and (4) causing minimal or no soil disturbance (NT). Additional supporting criteria are (1) adopting a holistic approach to sustainable management of agroecosystems, (2) providing three to five years of soil restoration phase while converting from long-term conventional PT to CA so that soil quality is sufficiently restored to fully harness its agronomic and ecological benefits, and (3) including improved crop varieties and genotypes that can also emit molecular-based signals under biotic/abiotic stresses detectable by remote sensing for targeted interventions.

Based on these criteria, CA is defined as a farming system comprised of crop residue mulch, cover cropping, INM, and NT techniques in a rotation cycle for effective soil and water conservation, SOC sequestration, sustainable intensification, and climate change adaptation and mitigation. The seemingly tall order is not only essential to advancing food and nutritional security but also critical to reducing GHG emissions by agriculture - presently estimated at 30\% of global total emissions (IPCC 2014, 2015; LeQuéré et al. 2014) — and minimizing the severe problems of nonpoint source pollution and contamination of surface waters including hypoxia (Diaz and Rosenberg 2008) and algal bloom (Michalak et al.

\section{Figure 1}

Historical evolution of plowing and conservation agriculture.

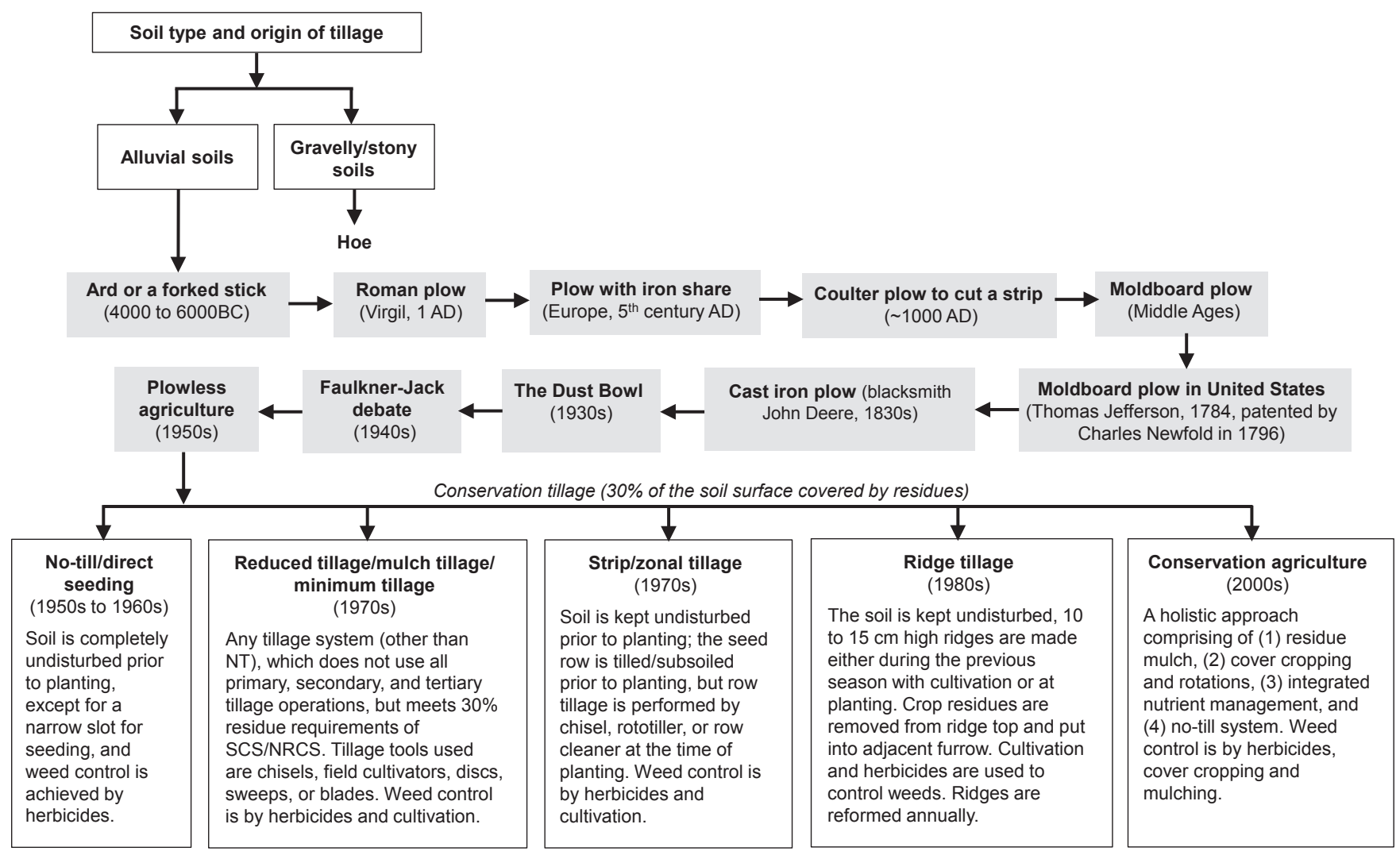




\section{Figure 2}

Four conceptual principles of conservation agriculture systems.

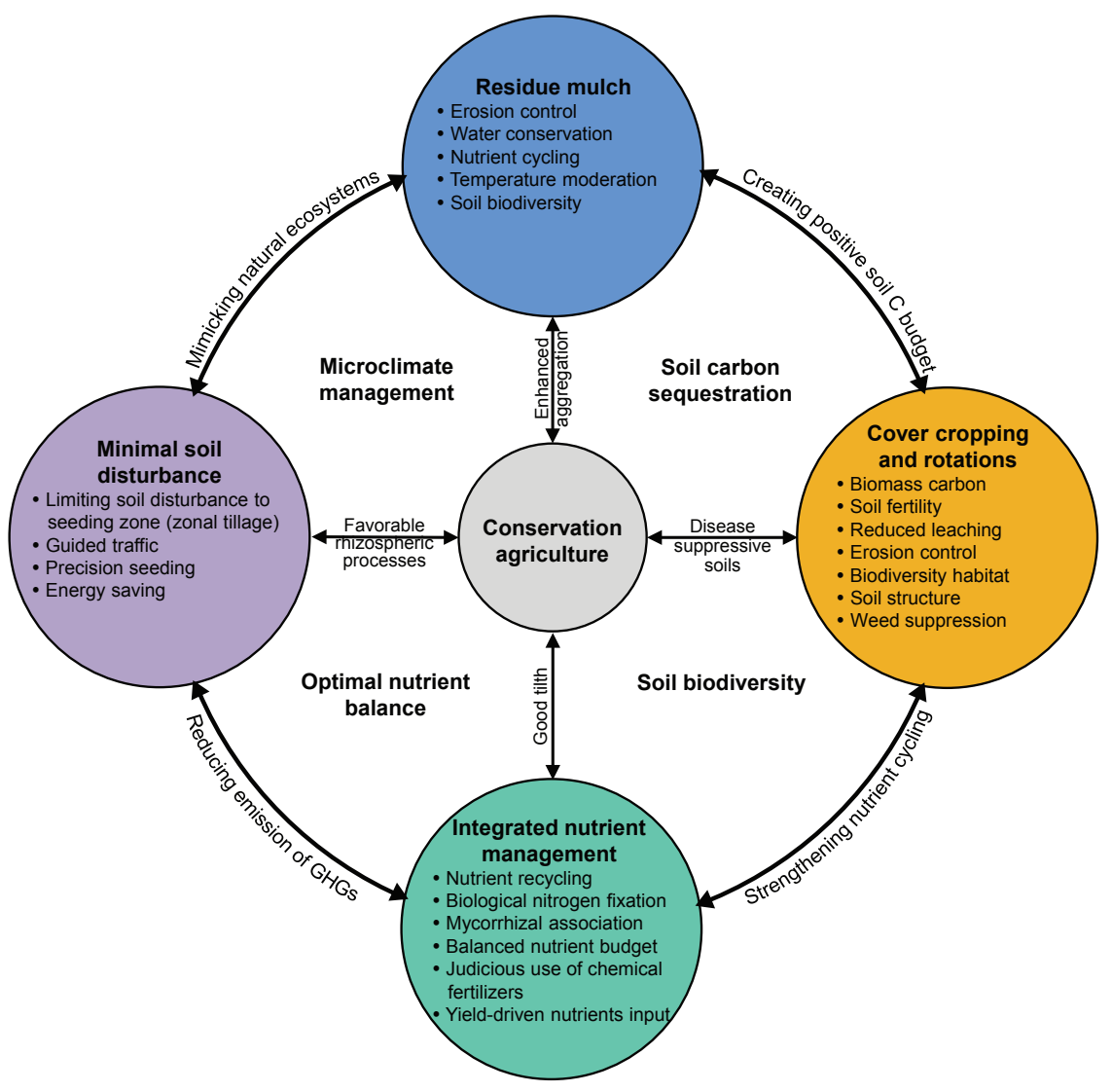

2013). In this context, the question is not whether CA works or not, but how to make it work by a strategy of identifying site-specific components. CA is a mission, a goal, and a long-term strategy of sustainable intensification of arable lands. The objective is not to produce the highest yield, but a sustainable optimum yield, especially during bad growing seasons. Thus, sustainability of a technology is judged not by the highest yield in a good season, but a respectable/stable yield in a poor season. This is the criterion of a climate-resilient management system.

\section{SOIL CARBON SEQUESTRATION}

An answer to whether conversion from PT to CA merely redistributes SOC in the profile rather than enhances it lies in a critical assessment of the equilibrium SOC pool under new management and its depth-distribution in relation to several exogenous (climate, physiography, and biome) and endogenous (soil properties) factors. Differences in input of biomass $\mathrm{C}$ is a main factor explaining variability in SOC sequestration under CA vs. PT (Virto et al. 2012). Differences in soil moisture and temperature regimes, and susceptibility to erosion among systems are other factors. Given favorable soil and climate and adoption of the holistic and farming system approach, there are examples from around the world of measurable gains in the SOC pool with conversion of PT to CA, not just in the surface (0 to 15 $\mathrm{cm}$ [0 to 6 in]) layer but also in subsoil to $50 \mathrm{~cm}$ (20 in) depth or more (table 1).

However, low rates of SOC sequestration are observed in arid regions and in seasons affected by drought. In South Dakota, United States, Clay et al. (2012) observed an SOC sequestration rate of 181 $\mathrm{kg} \mathrm{C} \mathrm{ha}^{-1}\left(161 \mathrm{lb} \mathrm{ac}^{-1}\right)$ during the drought seasons compared with $368 \mathrm{~kg} \mathrm{ha}^{-1}(328 \mathrm{lb}$ $\mathrm{ac}^{-1}$ ) for the long-term average. In addition to drought, temperature-sensitivity of SOC is also a factor whose response is not well understood (Davidson and Janssens 2006). Lower summertime soil temperatures in a CA system may reduce $\mathrm{CO}_{2}$ flux compared with that under PT (Sainju et al. 2008).

There are also several studies where a consistent and measurable increase in SOC under CA has not been observed. In contrast to the positive trends described above, review of literature on depth-distribution and total profile in relation to tillage methods indicates four distinct patterns: (1) no significant differences in SOC profile SOC pool among tillage treatments (Ludwig et al. 2011); (2) more SOC under PT than NT when assessed to $1 \mathrm{~m}(3 \mathrm{ft})$ depth or more (Li et al. 2007); (3) increase of SOC in the surface but decrease below the plow layer, indicating redistribution of the SOC pool because the cumulative totals are similar (Angers et al. 1997; Diaz-Zorita and Grove 2000; Doran et al. 1998; Xu et al. 2007); and (4) decrease in the SOC pool in both PT and CA systems as in landscapes prone to severe erosion (Olson et al. 2013). Declines in the SOC pool under NT are related to lower input of biomass $\mathrm{C}$ into the system, either because of low productivity or harvesting of residues (Kim et al. 2009). A study in southern Brazil on grain-based cropping systems and grazing indicated a linear relationship between SOC concentration and the annual $\mathrm{C}$ supply through plant biomass (Nicolso et al. 2008). The amount of biomass $\mathrm{C}$ required to maintain the $\mathrm{SOC}$ at the antecedent level differs among soils, climates, management systems, etc.

Different trends in depth distribution can partly be explained on the basis of the duration of tillage methods because NT takes three to five years or more to restore soil structure and enhance activity of soil biota. For a short period after conversion (less than five years), NT increases SOC concentration and pool compared to PT methods only in the surface layer but not for the entire soil profile (Deen and Kataki 2003; Powlson et al. 2014). Marked stratification of SOC in the surface layer under NT is attributed to application of crop residues and other biomass on the surface and incorporation within the plow layer. Thus, more SOC pool in PT below the plow layer than at equivalent depth has been commonly observed. In addition, subsoil properties (e.g., acidity, aluminum [Al] 
toxicity, phosphorus $[\mathrm{P}]$ and calcium $[\mathrm{Ca}]$ deficiency, pan or compaction, anaerobiosis, and water logging) have a strong impact on agronomic productivity (Pittelkow et al. 2014), the SOC pool, and its depth distribution. Specifically, P deficiency and low availability of Ca inhibit root development in the subsoil (Ritchey et al. 1980; Pavan et al. 1984) and decrease the SOC pool. In this regard, alleviation of root-restrictive attributes of subsoil is critical to increasing the SOC pool in the deeper horizon, which is also an important strategy to enhance the mean residence time of the SOC pool and enhance crop yield and total production.

Strong differences in the SOC pool among tillage methods and of trends in depth distribution are also caused by erosional processes. Globally, accelerated soil erosion by water leads to an estimated emission by as much as 1.1 Pg C $\mathrm{y}^{-1}\left(1.21\right.$ billion tn $\left.\mathrm{C} \mathrm{yr}^{-1}\right)$ (Lal 2003). Erosion-induced breakdown of aggregates and alterations in soil moisture and temperature regimes aggravate the depletion of the SOC pool onsite and emission of GHGs offsite (Lal 2003). Therefore, assessment of tillage-induced alterations in the SOC pool must take into account preferential removal of the SOC pool through erosion by water, wind, and other agents of erosion. The data from a 24-year conservation tillage experiment in southern Illinois showed that no SOC sequestration occurred in the sloping and eroding NT plots (Olson et al. 2013). For an Oxisol in the Brazilian Cerrado, Bayer et al. (2006) also observed that the SOC pool was maintained on cultivated land except when the soil had been subjected to erosion, which caused 15\% loss of the SOC pool. A modeling study on the effect of erosion on the SOC pool at the regional scale in Germany showed that mean SOC losses by erosion were up to $0.45 \mathrm{Mg} \mathrm{C} \mathrm{ha}^{-1} \mathrm{y}^{-1}\left(402 \mathrm{lb} \mathrm{C} \mathrm{ac}^{-1} \mathrm{yr}^{-1}\right)$ in agroecological zones covering the state territory of $35,742 \mathrm{~km}^{2}\left(13,800 \mathrm{mi}^{2}\right.$ ) (Gaiser et al. 2008). Gaiser and colleagues also estimated the $\mathrm{CO}_{2}$-C mitigation rate for this state upon conversion from $\mathrm{PT}$ to $\mathrm{NT}$ in the range of 0.08 to $1.83 \mathrm{Mg} \mathrm{C} \mathrm{ha}^{-1} \mathrm{y}^{-1}$ (71 to $1,634 \mathrm{lb} \mathrm{C}$ $\mathrm{ac}^{-1} \mathrm{yr}^{-1}$ ) even with accounting for the losses by erosion.

Therefore, it is important to identify which soil types, managements, and agroecoregions enhance or deplete SOC pools, why, and by what processes. This information is essential to developing systems which alleviate soil-related constraints, enhance soil C sink capacity, and create a positive soil/ecosystem C budget.

\section{CROP YIELD AND \\ AGRONOMIC SUSTAINABILITY}

Food and nutritional insecurity are global issues, but they are especially severe in developing countries because of population growth and declining availability of land, water, and other resources (Ray et al. 2015). Thus, sustainability of agronomic practices and increase in total production are essential to meeting the goals of increasing food supply. The challenge is especially daunting because of the changing and uncertain climate (Wilke and Morton 2015; Tubiello et al. 2007) and the attendant increase in risks of soil degradation (Bai et al. 2008). Because even a slight reduction in agronomic yield is not acceptable, a critical evaluation of crop response to a CA system is urgently warranted.

Soil quality is a strong determinant of agronomic yield. Thus, CA systems that enhance soil quality (such as those practiced in Brazil and elsewhere in South America) also improve and sustain productivity. There are examples from around

\section{Table 1}

Several studies that demonstrate an increase in soil organic carbon (SOC) under conversion to conservation agriculture.

\begin{tabular}{|c|c|c|c|c|c|}
\hline Location & $\begin{array}{l}\text { Study } \\
\text { duration }(y)\end{array}$ & Crop & $\begin{array}{l}\text { Depth } \\
\text { measured (cm) }\end{array}$ & $\begin{array}{l}\text { SOC }(\mathrm{MgC} \mathrm{ha-1}) \text { or } \\
\text { rate of change of SOC } \\
\text { pool }\left(\mathrm{kg} \mathrm{C} \mathrm{ha-1}^{-1}\right)^{*}\end{array}$ & Reference \\
\hline Huan Province, China & 4 & Rice & 80 & $\begin{array}{l}\text { NT (129.4), PT (126.3), } \\
\text { RT (122.5) }\end{array}$ & Xu et al. (2013) \\
\hline Georgia, United States & 41 & Corn, sorghum & 200 & NT (60), CR (52), FS (62) & Devine et al. (2011) \\
\hline Global (24 studies) & $>5$ & Grain crops & $>30$ & NT (100.3), PT (95.4) & Angers and Eriksen-Hamel (2008) \\
\hline Mediterranean Dryland & 16 & Barley & 40 & NT (50.5), PT (47.5) & Alvaro-Fuentes et al. (2008) \\
\hline Andes-Colombia (Andisols) & 7 & Potato & 117 & NT (1636), PT (1224) & Quintero and Commerford (2013) \\
\hline Southern Brazil & 11 to 20 & Grain crops & 100 & +640 to 1,170 & Sá et al. (2013) \\
\hline Southern Brazil & 22 & Grain crop & 40 & +994 & Sá et al. (2001) \\
\hline Central Brazil (Cerrado) & 1 to 13 & Soybean & 40 & +400 to 1,700 & Blanchart et al. (2007) \\
\hline Madagascar Highlands & 7 & Corn-soybean & 20 & +590 to 1,050 & Sá et al. (2008) \\
\hline North Central United States & - & Cotton & - & +430 & Causarano et al. (2005) \\
\hline United States & 5 & Corn-soybean & - & +900 & Hollinger et al. (2005) \\
\hline Southeastern United States & - & Cotton & - & +428 & Causarano et al. (2005) \\
\hline Michigan, United States & 12 & Corn-soybean-wheat & 100 & +330 to 500 & Syswerda et al. (2011) \\
\hline $\begin{array}{l}\text { Western Canada and } \\
\text { United States }\end{array}$ & $\begin{array}{r}10 \text { to } 40 \\
4 \text { to } 56\end{array}$ & Wheat, barley & - & +80 to 460 & Liebig et al. (2005) \\
\hline Canada, Prairies & - & Grain crops & - & +312 to 544 & West and Post (2002) \\
\hline Southeastern Australia & 20 & Grain crops & - & +180 to 315 & Grace et al. (2010) \\
\hline Global (67 studies) & 5 to 60 & Grain crops & - & +300 & Janzen et al. (1998) \\
\hline Global (52 Studies) & - & Grain crops & - & +47 to 620 & Puget and Lal (2005) \\
\hline
\end{tabular}

Notes: $\mathrm{NT}=$ not-till. $\mathrm{PT}=$ plow tillage. $\mathrm{RT}=$ rotary tillage. $\mathrm{FS}=$ Forest system.

* Above the horizontal rule are measured SOC pools; below the horizontal rule are rates of change in the SOC pool. 
the world where properly implemented CA systems have improved soil quality and agronomic yields, including some from the US Central Great Plains (Mikha et al. 2012) and Corn Belt (Al Kaisi et al. 2005; Triplett and Dick 2008) region. Positive effects on soil physical quality (structure and water infiltration rate) are especially relevant to erosion control in erosive climate and erodible soils of the tropics (Lal 1976a, Lal 1976b; Choudhury et al. 2014) and elsewhere (Li et al. 2011; Kheyrodin and Antoun 2011). Soil moisture conservation by $\mathrm{NT}$ is an important advantage even in industrial agriculture, as was the case during the summer drought of 2012 in the US Corn Belt (Lal et al. 2012; Goode 2015). In these situations, conversion to CA can also improve soil biological quality with respect to microbial communities (Gupta et al. 2008; Zhang et al. 2012; Mathew et al. 2012), microbial growth and decomposition processes (Franzluebbers et al. 1995), soil food web and C dynamics (Minoshima et al. 2006), earthworms (Lal 1975, Lal 1976a; Edwards et al. 1988; Parmelee et al.1990), and other macrofauna (Mutema et al. 2013). The $\mathrm{CA}$-caused increase in SOC concentration even in the surface layer and reduction in soil erosion and improvement in biological properties also enhance soil fertility and chemical attributes (Lal 1975; Triplett and Dick 2008; Kheyrodin and Antoun 2011), ameliorate sodic soils (Choudhury et al. 2014), and improve agronomic pro- ductivity. With proper implementation, there are examples of better yield in NT than in PT, especially in well-drained soils prone to water runoff and accelerated erosion (Zhang et al. 2009; Liao et al. 2015; Moraru and Rusu 2013).

In contrast, there are also numerous examples of significant reductions in agronomic yields with NT. This declining yield trend sets-in-motion a vicious cycle of decreasing biomass causing low SOC pools, which result in lower yields, low biomass input, lower soil quality, and finally, even lower yields. Thus, it is utterly important, to identify the cause and effect relationship, determine site-specific soil and ecosystemrelated constraints, and develop strategies to alleviate the yield-limiting barriers so that ecologic, climatic, and environmental benefits of CA systems can be fully harnessed. In degraded soils, a successful adoption of CA without prior amelioration can be a myth rather than a reality, especially for resourcepoor farmers and small landholders of the tropics and subtropics.

Indeed, there are several known reasons for reduction in crop yield under NT, particularly within two to three years after conversion from PT to NT (table 2). Important among these are (1) low crop stand due to insufficient seed-soil contact and poor seeding equipment that accumulates residues in front of the seeder rather than cutting through it, (2) stunted seedling growth because of suboptimal soil temperatures during cold and wet springs in higher latitudes, (3) soil compaction in the row zone, (4) immobilization of $\mathrm{N}$ by residues of large C:N ratio and low availability of other plant nutrients, (5) ineffective weed control and a shift towards perennial weeds, and (6) increase in incidence of pests and pathogens under NT including seedling damage by slugs in a damp and cold spring (Wahlen et al. 2010).

With examples of some of these constraints outlined in table 2, it would be presumptuous to accept that agronomic practices developed for PT methods of seedbed preparation can be used for the CA system. The need for development of BMPs specific to CA system has been recognized since the 1980s (Lal 1983) and must be objectively considered and actively pursued.

\section{DEVELOPING A HOLISTIC SYSTEM APPROACH}

Daunting and challenging task as it may seem, there is little choice but to integrate four basic/conceptual components into a system for the success of CA (figure 3) (Lal 1987). Implementing CA as a single element (eliminating plowing but removing crop residues) rather than a package is not acceptable. A sufficient quantity of crop residue mulch, use of a cover crop (preferably leguminous with a deep root system), adequate soil fertility, and proper crop rotations are essential components of a complete CA package. There are economic, ecologic, and social costs involved

\section{Table 2}

Some examples of specific causes of yield reductions under no-tillage systems.

\begin{tabular}{|c|c|c|c|c|}
\hline Country/region & Agroecosystem & Crop & $\begin{array}{l}\text { Cause of yield reduction } \\
\text { by NT/CA }\end{array}$ & Reference \\
\hline Australia & Grain crops & Wheat & Reduced early seedling growth & Kirkegaard (1995) \\
\hline Burkina Faso & Ferruginous tropical soil & Cotton, sorghum, maize & $\mathrm{N}$ deficiency & Soler et al. (2011) \\
\hline China & Loess Plateau & Wheat, peas & Stubble removal & Huang et al. (2008) \\
\hline Japan & Andosol & Wheat, barley, rape & $P$ deficiency & Tsuji et al. (2006) \\
\hline Mediterranean & Arid & Maize, sunflower & Poor establishment & Farina et al. (2011) \\
\hline Mexico & Rainfed & Maize & Stubble removal & Verhulst et al. (2011) \\
\hline United States & Tenessee Vallet & Cotton, corn, rye & $\mathrm{N}$ availability & Reddy et al. (2009) \\
\hline Northwestern United States & Palouse (Northern Idaho) & Wheat & Greater root disease pressure & Hammel (1995) \\
\hline Pacific Northwest, United States & Colombia Basin & Wheat & Downy brome weed & Camara et al. (2003) \\
\hline $\begin{array}{l}\text { Western Great Plains, } \\
\text { United States }\end{array}$ & Semiarid & Wheat, maize, sorghum & $\begin{array}{l}\mathrm{N} \text { management and } \\
\text { use efficiency }\end{array}$ & Kolberg et al. (1996) \\
\hline Uzbekistan & Grain crops & Wheat & $\begin{array}{c}\text { Partial crop residue retention, } \\
\text { not using the full system }\end{array}$ & Kienzler et al. (2012) \\
\hline
\end{tabular}

Notes: $\mathrm{N}=$ nitrogen. $\mathrm{P}=$ phosphorus. 
in each of these inputs. Carbon sequestration in soil can happen only when CA or any other system can create a positive soil $\mathrm{C}$ budget, which has additional inputs and costs associated with residue mulch, fertilizers, herbicides, etc. Farmers must be fairly compensated for the societal value of humus or SOC sequestered (Lal 2014). Input of $\mathrm{C}$ from crop residues and cover crops are important to offset losses by decomposition, erosion, and leaching.

The humongous and complex problem of global warming necessitates critical review of all options (including geoengineering). Some of these strategies (i.e., CA) may cause only a modest reduction or drawdown of atmospheric $\mathrm{CO}_{2}$. Thus, choice of these strategies must be based on additional co-benefits, cost-effectiveness, and social/cultural acceptability. In this regard, CA is an important mitigation option that deserves a serious and objective consideration. By itself, it cannot address climate change, but can make an incremental contribution along with other technologies and also produce several co-benefits.

Farmers are interested in feeding their families or making profit. If CA also helps in climate change adaptation and improves the environment, so be it, but that may not be among major goals of a farmer. Therefore, yield reduction from CA, especially during the initial stages of its implementation, must be objectively addressed. The yield-limiting constraints (e.g., weeds, pests, low crop stand, stunted seedling growth, subsoil compaction, and nutrient imbalance) must be alleviated, because even a slight yield reduction may be a major deterrent-for some farmers

\section{Figure 3}

Conceptual outline of conservation agriculture based on four basic principles (mulch, cover crop, integrated nutrient management [INM], and minimal soil disturbance or no-till). The INM involves judicious use of chemical and biofertilizers and nutrient cycling (rhizobia nodules and mycorrhizal fungi). Improved varieties, including those which emit molecular signals under stress and detectable by remote sensing, allow for targeted interventions.

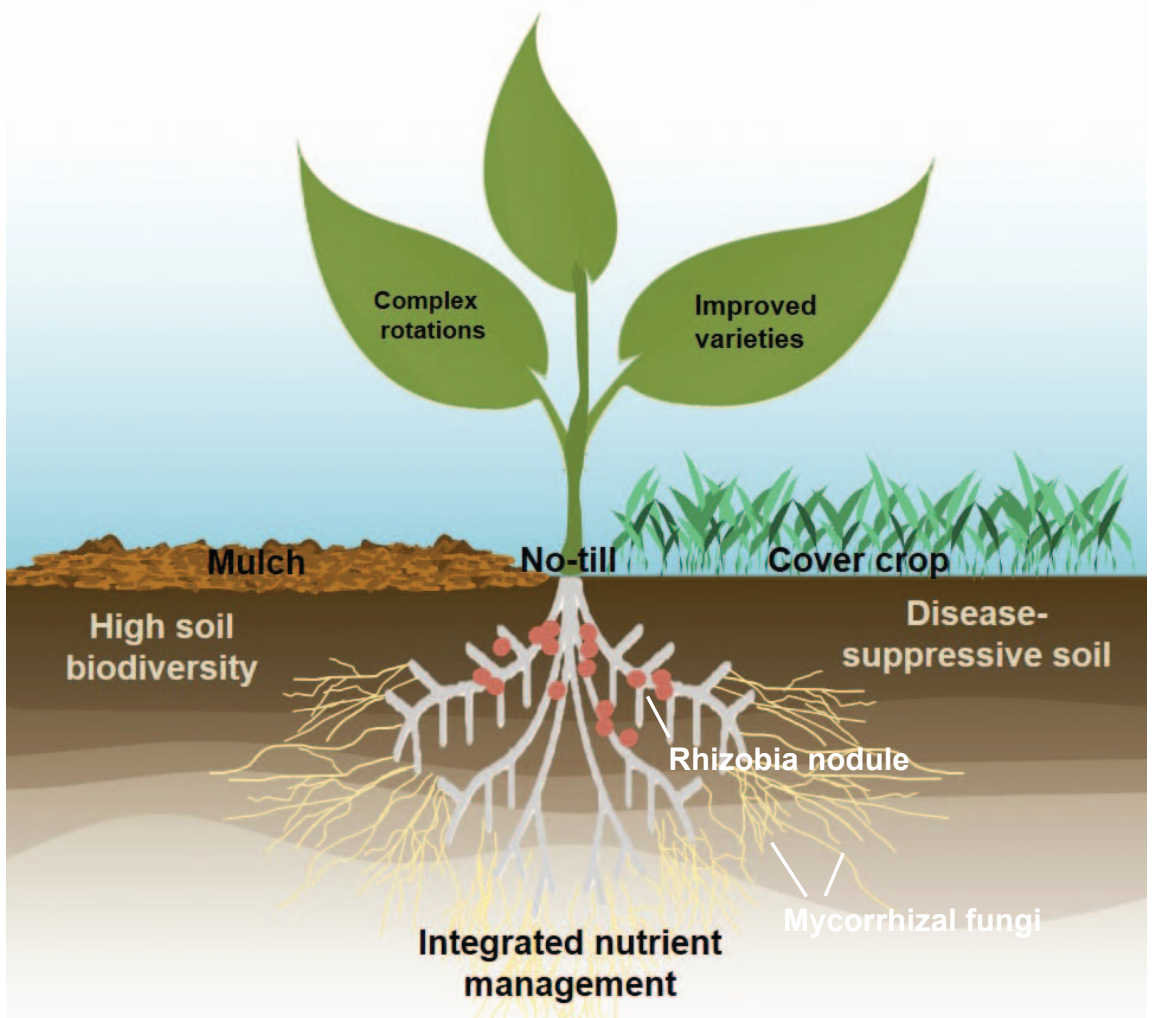

any amount of yield reduction is too much and is not acceptable.

Thus, it is pertinent to develop and implement an appropriate package of farm operations and cultural practices specifically designed for a CA system, along with the concept of the stewardship of soil resources. Soil stewardship and care must be embedded in every fruit and vegetable eaten, in each grain ground into the bread consumed, in every cup of water used, in every breath of air inhaled, and in every scenic landscape cherished. It is precisely in this context that CA is an important innovation and a mission for the 21 st century.

\section{REFERENCE}

Al-Kaisi, M.M., X.H. Yin, and M.A. Licht. 2005. Soil carbon and nitrogen changes as influenced by tillage and cropping systems in some Iowa soils. Agriculture Ecosystems \& Environment 105(4):635-647.

Alvaro-Fuentes, J., M.V. Lopez, C. Cantero-Martinez, and J.L. Arrue. 2008. Tillage effects on in Mediterranean soil organic carbon fractions dryland agroecosystems. Soil Science Society of America Journal 72(2):541-547.

Angers, D.A., and N.S. Eriksen-Hamel. 2008. Fullinversion tillage and organic carbon distribution in soil profiles: A meta-analysis. Soil Science Society of America Journal 72(5):1370-1374.

Angers, D.A., M.A. Bolinder, M.R. Carter, E.G. Gregorich, C.F. Drury, B.C. Liang, R.P. Voroney, R.R. Simard, R.G. Donald, R.P. Beyaert, and J. Martel. 1997. Impact of tillage practices on organic carbon and nitrogen storage in cool, humid soils of eastern Canada. Soil \& Tillage Research 41(3-4):191-201.

Bai, Z.G., D.L. Dent, L. Olsen, and M.E. Schaepman. 2008. Proxy global assessment of land degradation. Soil Use and Management 24:233-234.

Bayer, C., L. Martin-Neto, J. Mielniczuk, A. Pavinato, and J. Dieckow. 2006. Carbon sequestration in two Brazilian Cerrado soils under no-till. Soil \& Tillage Research 86(2):237-245.

Blanchart, E., M. Bernoux, X. Sarda, M. Siqueira Neto, C.C. Cerri, M. Piccolo, J. Douzet, E. Scopel, and C. Feller. 2007. Effect of direct seeding mulch-based systems on soil carbon storage and macrofauna in Central Brazil. Agriculturae Conspectus Scientificus 72:81-87.

Bockstaller, C., L. Guichard, D. Makowski, A. Aveline, P. Girardin, and S. Plantureux. 2008. Agri-environmental indicators to assess cropping and farming systems. A review. Agronomy for Sustainable Development 28(1):139-149.

Camara, K.M.,W.A. Payne, and P.E. Rasmussen. 2003. Long-term effects of tillage, nitrogen, and rainfall on winter wheat yields in the Pacific Northwest. Agronomy Journal 95(4):828-835.

Causarano, H., A.J. Franzluebbers, D.W. Reeves, J.N. Shaw, and M.L. Norfleet. 2005. Potential for soil carbon sequestration in cotton production systems of the southeastern USA. Washington, DC: USDA. 
Choudhury, S.G., S. Srivastava, R. Singh, S.K Chaudhari, D.K. Sharma, S.K. Singh, and D. Sarkar. 2014. Tillage and residue management effects on soil aggregation, organic carbon dynamics and yield attribute in rice-wheat cropping system under reclaimed sodic soil. Soil \& Tillage Research 136:76-83.

Clay, D.E., J.Y. Chang, S.A. Clay, J. Stone, R.H. Gelderman, G.C. Carlson, K. Reitsma, M. Jones, L. Janssen, and T. Schumacher. 2012. Corn yields and no-tillage affects carbon sequestration and carbon footprints. Agronomy Journal 104(3):763-770.

Crowley, T.J. 1995. Ice-age terrestrial carbon changes revisited. Global Biogeochemical Cycles 9(3):377-389.

Davidson, E.A., and I.A. Janssens. 2006. Temperature sensitivity of soil carbon decomposition and feedbacks to climate change. Nature 440(7081):165-173.

Deen, W., and P.K. Kataki. 2003. Carbon sequestration in a long-term conventional versus conservation tillage experiment. Soil \& Tillage Research 74(2):143-150.

Devine, S., D. Markewitz, P. Hendrix, and D. Coleman. 2011. Soil carbon change through $2 \mathrm{~m}$ during forest succession alongside a 30-year agroecosystem experiment. Forest Science 57(1):36-50.

Diaz-Zorita, M., and J.H. Grove. 2000. The greater carbon sequestration in co-till soil depends upon its distribution with depth. 23rd Annual Southern Conservation Tillage Conference for Sustainable Agriculture, Monroe, Louisiana.

Diaz, R.J., and R. Rosenberg. 2008. Spreading dead zones and consequences for marine ecosystems. Science 321(5891):926-929.

Doran, J.W., E.T. Elliott, and K. Paustian. 1998. Soil microbial activity, nitrogen cycling, and longterm changes in organic carbon pools as related to fallow tillage management. Soil \& Tillage Research 49(1-2):3-18.

Edwards, W.M., L.D. Norton, and C.E. Redmond. 1988. Characterizing macropores that affect infiltration into non-tilled soil. Soil Science Society of America Journal 52:483-487.

Falkowski, P., R.J. Scholes, E. Boyle, J. Canadell, D. Canfield, J. Elser, N. Gruber, K. Hibbard, P. Hogberg, S. Linder, F.T. Mackenzie, B. Moore, T. Pedersen, Y. Rosenthal, S. Seitzinger,V. Smetacek, and W. Steffen. 2000. The global carbon cycle: A test of our knowledge of earth as a system. Science 290(5490):291-296.

Farina, R., G. Seddaiu, R. Orsini, E. Steglich, P.P. Roggero, and R. Francaviglia. 2011. Soil carbon dynamics and crop productivity as influenced by climate change in a rainfed cereal system under contrasting tillage using EPIC. Soil \& Tillage Research 112(1):36-46.

Faulkner, E.H. 1943. Plowman's Folly. Norman, OK: University of Oklahoma Press.

Franzluebbers, A.J., F.M. Hons, and D.A. Zuberer. 1995. Soil organic-carbon, microbial biomass, and mineralizable carbon and nitrogen in sorghum. Soil Science Society of America Journal 59(2):460-466.

Gaiser,T., K.Stahr,N.Billen, and M.A.R. Mohammad. 2008. Modeling carbon sequestration under zero tillage at the regional scale. I. The effect of soil erosion. Ecological Modelling 218(1-2):110-120.
Goode, E. 2015. Farmers put down the plow for more productive soils. The New York Times, Science Section, 10 March. http://nyti.ms/1A9ok7B.

Grace, P.R., J. Antle, S. Ogle, K. Paustian, and B. Basso. 2010. Soil carbon sequestration rates and associated economic costs for farming systems of south-eastern Australia. Australian Journal of Soil Research 48(8):720-729.

Gupta, V., D. Roget, C. Davoren, R. Llewllyn, and A. Whitbread. 2008. Farming system impacts on microbial activity and soil organic matter dynamics in southern Australian Mallee soils. In Australian Agronomy Conference.

Hammel, J.E. 1995. Long-term tillage and croprotation effects on winter-wheat production in northern Idaho. Agronomy Journal 87(1):16-22.

Hammons, S.K. 2009. Re-examining the relationship between tillage regime and global climate change. Journal of Natural Resources \& Life Sciences Education 38:144-147.

Hollinger, S.E., C.J. Bernacchi, and T.P. Meyers. 2005. Carbon budget of mature no-till ecosystem in North Central Region of the United States. Agricultural and Forest Meteorology 130(1-2):59-69.

Huang, G.B., R.Z. Zhang, G.D. Li, L.L. Li, K.Y Chan, D.P. Heenan, W. Chen, M.J. Unkovich, M.J. Robertson, B.R. Cullis, and W.D. Bellotti. 2008 Productivity and sustainability of a spring wheatfield pea rotation in a semi-arid environment under conventional and conservation tillage systems. Field Crops Research 107(1):43-55.

IPCC (Intergovernmental Panel on Climate Change). 2014. Climate Change 2013: Executive Summary Geneva, Switzerland: Intergovernmental Panel on Climate Change.

IPCC. 2015. Climate Change 2014: Synthesis Report. Geneva, Switzerland: Intergovernmental Panel on Climate Change.

Jack, W.T. 1946. The Furrow and Us. Philadelphia: Dorrance.

Jack, Z.M. 2007. "Dirt farmer" vs. "soil scientist:" Representative tension in the constructed identities of farmer-writers Walter Thomas Jack and Edward H. Faulkner. Southern Rural Sociology 22:40-64

Janzen, H.H., C.A. Campbell, R.C. Izaurralde, B.H Ellert, N. Juma, W.B. McGill, and R.P. Zentner 1998. Management effects on soil C storage on the Canadian prairies. Soil \& Tillage Research 47(3-4):181-195.

Kheyrodin, H., and H. Antoun. 2011. Tillage and manure effect on soil physical and chemical properties and on carbon and nitrogen mineralization potentials. African Journal of Biotechnology 10(48):9824-9830.

Kienzler, K.M., J.P. Lamers, A. McDonald, A Mirzabaev, N. Ibragimov, O. Egamberdiev, E. Ruzibaev, and A. Akramkhanov. 2012 Conservation agriculture in Central Asia-What do we know and where do we go from here? Field Crops Research 132:95-105.

Kim, S., B.E. Dale, and R. Jenkins. 2009. Life cycle assessment of corn grain and corn stover in the United States. International Journal of Life Cycle Assessment 14(2):160-174.

Kirkegaard, J.A., M.K. Conyers, J.R. Hunt, C.A Kirkby, M. Watt, and G.J. Rebetzke. 2014 Sense and nonsense in conservation agriculture: Principles, pragmatism and productivity in
Australian mixed farming systems. Agriculture Ecosystems \& Environment 187:133-145.

Kirkegaard, J.A. 1995. A review of trends in wheat yield responses to conservation cropping in Australia. Australian Journal of Experimental Agriculture 35(7):835-848.

Kolberg, R.L., N.R. Kitchen, D.G. Westfall, and G.A Peterson. 1996. Tillage systems - Cropping intensity and nitrogen management impact of dryland notill rotations in the semi-arid western Great Plains. Journal of Production Agriculture 9(4):517-522.

Lal, R. 1975. Role of mulching techniques in tropical soil and water management. International Institute of Tropical Agriculture Technical. Bulletin 1. Ibadan, Nigeria: International Institute of Tropical Agriculture.

Lal, R. 1976a. No-tillage effects on soil properties under different crops in western Nigeria. Soil Science Society of America Proceedings 40:762-768

Lal, R. 1976b. Soil erosion of Alfisols in western Nigeria. III. Effect of rainfall characteristics. Geoderma 16:389-401.

Lal, R. 1983. No-till Farming. International Institute of Tropical Agriculture Technical Bulletin.1. Ibadan, Nigeria: International Institute of Tropical Agriculture.

Lal, R. 1987. Managing soils of sub-Saharan Africa. Science 236:1069-1076.

Lal, R. 2003. Soil erosion and the global carbon budget. Environment International 29:437-450.

Lal, R. 2004. Soil carbon sequestration impacts on global climate change and food security. Science 304:1623-1627.

Lal, R. 2009. The plow and agricultural sustainability. Journal of Sustainability \& Agriculture 33:66-84.

Lal, R. 2014. Societal value of soil carbon. Journal of Soil and Water Conservation 69(6):186A-192A, doi:10.2489/jswc.69.6.186A.

Lal, R. D.C. Reicosky, and J.D. Hanson. 2007. Evolution of plow over 10,000 years and the rationale for no-till farming. Soil and Tillage Research 93:1-12.

Lal, R., J.A. Delgado, J. Gulliford, D. Nielsen, C.W. Rice and R.S.Van Pelt. 2012. Adapting agriculture to drought and extreme events. Journal of Soil and Water Conservation 67(6):162A-166A, doi:10.2489/jswc.67.6.162A.

LeQuéré, C.L., G.P. Peters, R.J.Andres, R.M.Andrew, T.A. Boden et al. 2014. Global C budget. 2013. Earth System Science Data 6:235-263.

Li, L.L., K.Y. Chan, Y.N. Niu, G.D. Li, A. Oates, A. Dexter, and G.B. Huang. 2011. Soil physical qualities in an Oxic Paleustalf under different tillage and stubble management practices and application of S theory. Soil \& Tillage Research 113(2):82-88.

Li, Z., D. Xu, A. Fum, X. Sun, and J. Xi. 2007. Effect of land-use change on vertical distribution and storage of soil organic carbon in north subtropical areas. Forest Research 20:744-749.

Liao, Y., W.L.Wu, F.Q. Meng and R. Lal. 2015. Increase in soil organic carbon by agricultural intensification in northern China. Biogeoscience 12:1403-1413.

Liebig, M.A., J.A. Morgan, J.D. Reeder, B.H. Ellert, H.T. Gollany, and G.E. Schuman. 2005. Greenhouse gas contributions and mitigation potential of agricultural practices in northwestern USA and western Canada. Soil \& Tillage Research 83(1):25-52. 
Ludwig, B., D. Geisseler, K. Michel, R.G. Joergensen, E. Schulz, I. Merbach, J. Raupp, R. Rauber, K. Hu, L. Niu, and X. Liu. 2011. Effects of fertilization and soil management on crop yields and carbon stabilization in soils. A review. Agronomy For Sustainable Development 31(2):361-372.

Mathew, R.P., Y. Feng, L. Githinji, R. Ankumah, and K.S. Balkcom. 2012. Impact of no-tillage and conventional tillage systems on soil microbial communities. Applied and Environmental Soil Science 2012:1-10.

Michalak, A.M., E.J. Anderson, D. Beletsky, S. Boland, N.S. Bosch, T.B. Bridgeman, J.D. Chaffin, K. Cho, R. Confesor, I. Daloglu, J.V. DePinto, M.A. Evans, G.L. Fahnenstiel, L.L. He, J.C. Ho, L. Jenkins, T.H. Johengen, K.C. Kuo, E. LaPorte, X.J. Liu, M.R. McWilliams, M.R. Moore, D.J. Posselt, R.P. Richards, D. Scavia, A.L. Steiner, E. Verhamme, D.M. Wright, and M.A. Zagorski. 2013. Recordsetting algal bloom in Lake Erie caused by agricultural and meteorological trends consistent with expected future conditions. Proceedings of the National Academy of Sciences of the United States of America 110(16):6448-6452.

Mikha, M., M.F. Vigil, and J.G. Benjamin. 2012. Long-term tillage impacts on soil aggregation and carbon dynamics under wheat-fallow in the Central Great Plains. Soil Science Society of America Journal 77:594-605.

Minoshima, H., L.E. Jackson, T.R. Cavagnaro, S. Sanchez-Moreno, H. Ferris, S.R. Temple, S. Goyal, and J.P. Mitchell. 2007. Soil food webs and carbon dynamics in response to conservation tillage in California. Soil Science Society of America Journal 71(3):952-963.

Moraru, P.I., and T. Rusu. 2013. Effect of different tillage systems on soil properties and production on wheat, maize, and soybean crop. International Scholarly and Scientific Research \& Innovation 7:679-692.

Mutema, M., P.L. Mafongoya, I. Nyagumbo, and L. Chikukura. 2013. Effects of crop residues and reduced tillage on macrofauna abundance. Journal of Organic Systems 8:5-16.

Nicolso, R.S., T. Lovato, T.J.C. Amado, C. Bayer, and M.E. Lanzanova. 2008. Balanço do carbon orgânico no colo sob interactao lavoura-pecuária no sul do Brasil. Brazilian Journal of Soil Science 32:2425-2433.

Olson, K.R., S.A. Ebelhar, and J.M. Lang. 2013. Effects of 24 years of conservation tillage systems on soil organic carbon and soil productivity. Applied and Environmental Soil Science 2013:1-10.

Parmelee, R.W., M.H. Beare, W. Cheng, P.F. Hendrix, S.J.Rider, D.A. Crossley, and D.C. Coleman. 1990. Earthworms and enchytaeids in conventional and no-tillage agroecosystems - a biocide approach to assess their role in organic-matter breakdown. Biology and Fertility of Soils 10(1):1-10.

Pavan, M.A., F.T. Bingham, and P.F. Pratt. 1984. Redistribution of exchangeable calcium, magnesium, and aluminum following lime or gypsum applications to a Brazilian oxisol. Soil Science Society of America Journal 48(1):33-38.

Pittelkow, C.M., X. Laing, B.A. Linquist, K.J. van Groenigen, J. Lee et al. 2014. Productivity limits and potential of the principles of conservation agriculture. Nature Research Letters 517:365-234.
Powlson, D.S., C. Mistirling, M.L. Jat, B.G. Gerard, C.A. Palm, P.A. Sanchez, and K.G. Cassman. 2014. Limited potential of no-till agriculture for climate change mitigation. Nature Climate Change 4:678-683.

Puget, P., and R. Lal. 2005. Soil organic carbon and nitrogen in a Mollisol in central Ohio as affected by tillage and land use. Soil \& Tillage Research 80(1-2):201-213.

Quintero, M., and N.B. Comerford. 2013. Effects of conservation tillage on total and aggregated soil organic carbon in the Andes. Open Journal of Soil Science 3:361-373.

Rasmussen, P.E., K.W.T. Goulding, J.R. Brown, P.R. Grace, H.H. Janzen, and M. Korschens. 1998. Agroecosystem-Long-term agroecosystem experiments: Assessing agricultural sustainability and global change. Science 282(5390):893-896.

Ray, D.K., J.S. Gerber, G.K. MacDonald, and P.C. West. 2015. Climate variation explains a third of global cop yield variability. Nature Communications 6:1-9.

Reddy, S.S., E.Z. Nyakatawa, K.C.Reddy, R.L.Raper, D.W. Reeves, and J.L. Lemunyon. 2009. Longterm effects of poultry litter and conservation tillage on crop yields and soil phosphorus in cotton-cotton-corn rotation. Field Crops Research 114(2):311-319.

Ritchey, K.D., D.M.G. Souza, E. Lobato, and O. Correa. 1980. Calcium leaching to increase rooting depth in a Brazilian savannah oxisol. Agronomy Journal 72(1):40-44.

Running, S.W. 2008. Climate change - Ecosystem disturbance, carbon, and climate. Science 321(5889):652-653.

Sá, J., L. Seguy, E. Goze, S. Bouzinac, O. Husson, S. Boulakia, F. Tivet, F. Forest, and J. Santos. 2008. Carbon sequestration rates in no-tillage soils under intensive cropping systems in tropical agroecozones. Rome: Food and Agriculture Organization.

Sa, J.C.D.M., J.B. dos Santos, R. Lal, A. de Moraes, F. Tivet, M.F.M. Sa, C. Briedis, A.D.O. Ferreira, G. Eurich,A. Farias, and T. Friedrich. 2013. Soil-specific inventories of landscape carbon and nitrogen stocks under no-till and native vegetation to estimate carbon offset in a subtropical ecosystem. Soil Science Society of America Journal 77 (6):2094-2110.

Sá, J.C.D., C.C. Cerri, W.A. Dick, R. Lal, S.P.Venske, M.C. Piccolo, and B.E. Feigl. 2001. Organic matter dynamics and carbon sequestration rates for a tillage chronosequence in a Brazilian Oxisol. Soil Science Society of America Journal 65(5):1486-1499.

Sainju, U.M., J.D. Jabro, and W.B. Stevens. 2008. Soil carbon dioxide emission as influenced by irrigation, tillage, cropping system, and nitrogen fertilization. Journal of Environmental Quality 37(1):98-106.

Schlesinger,W.H. 2000. Carbon sequestration in soils: Some cautions amidst optimism. Agriculture Ecosystems \& Environment 82(1-3):121-127.

Soler, C.M.T.,V.B. Bado, K.Traore, W.M. Bostick, J.W. Jones, and G. Hoogenboom. 2011. Soil organic carbon dynamics and crop yield for different crop rotations in a degraded ferruginous tropical soil in a semi-arid region: a simulation approach. Journal of Agricultural Science 149:579-593.

Song, G.H., L.Q. Li, G.X. Pan, and Q. Zhang. 2005. Topsoil organic carbon storage of China and its loss by cultivation. Biogeochemistry 74(1):47-62.
Steinbeck, J. 1939. Grapes of Wrath. New York: Viking Press.

Syswerda, S.P., A.T. Corbin, D.L. Mokma, A.N. Kravchenko, and G.P. Robertson. 2011. Agricultural management and soil carbon storage in surface vs. deep layers. Soil Science Society of America Journal 75(1):92-101.

Tennesen, M. 2014. Rare earth: Scientists are tracking down rare and endangered soils in a quest to document and preserve "pedodiversity." Science 346:692-695.

Triplett, G.B., and W.A. Dick. 2008. No-tillage crop production: A revolution in agriculture! Agronomy Journal 100(3):S153-S165.

Tsuji, H., H. Yamamoto, K. Matsuo, and K. Usuki. 2006. The effects of long-term conservation tillage, crop residues and $\mathrm{P}$ fertilizer on soil conditions and responses of summer and winter crops on an Andosol in Japan. Soil \& Tillage Research 89(2):167-176.

Tubiello, F.N., J.F. Soussana, and S.M. Howden. 2007. Crop and pasture response to climate change. Proceedings of the National Academy of Sciences of the United States of America 104(50):19686-19690.

United Nations. 2014. World Population Prospects: the 2012 Revision (updated 16th April 2014). New York: United Nations.

Verhulst, N., V. Nelissen, N. Jespers, H. Haven, K.D. Sayre, D. Raes, J. Deckers, and B. Govaerts. 2011. Soil water content, maize yield and its stability as affected by tillage and crop residue management in rainfed semi-arid highlands. Plant and Soil 344(1-2):73-85.

Virto, I., P. Barre, A. Burlot, and C. Chenu. 2012. Carbon input differences as the main factor explaining the variability in soil organic C storage in no-tilled compared to inversion tilled agrosystems. Biogeochemistry 108(1-3):17-26.

Wahlen, J., B. Cissel, and P. Sylvester. 2010. Chemical management of slugs in no-till corn and soybean system. University of Delaware.

West, T.O., and W.M. Post. 2002. Soil organic carbon sequestration rates by tillage and crop rotation: A global data analysis. Soil Science Society of America Journal 66(6):1930-1946.

Wilke, A.K., and L.W. Morton. 2015. Climatologists' patterns of conveying climate science to the agricultural community. Agriculture and Human Values 32(1):99-110

Xu, S.Q., M.Y. Zhang, H.L. Zhang, F. Chen, G.L. Yang, and X.P. Xiao. 2013. Soil organic carbon stocks as affected by tillage systems in a doublecropped rice field. Pedosphere 23(5):696-704.

Xu, Y., W. Chen, and Q. Shen. 2007. Soil carbon and nitrogen pools impacted by long-term tillage and fertilization practices. Communications in Soil Science and Plant Analysis 38:347-357.

Zhang, B., H.B. He, X.L. Ding, X.D. Zhang, X.P. Zhang, X.M. Yang, and T.R. Filley. 2012. Soil microbial community dynamics over a maize (Zea mays L.) growing season under conventional- and no-tillage practices in a rainfed agroecosystem. Soil \& Tillage Research 124:153-160.

Zhang, X., H. Li, J. He, Q. Wang, and M. Golabi. 2009. Influence of conservation tillage practices on soil properties and crop yields for maize and wheat cultivation in Beijing, China. Australian Journal of Soil Research 47:362-371. 